\title{
A ARTE DA TRADUÇÃO
}

\author{
THE ART OF TRANSLATION
}

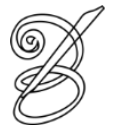 \\ Tahne Bohrer Martins ${ }^{\mathrm{i}}$ \\ Pós-graduanda da Faculdade de Letras da PUCRS \\ tahnemartins@hotmail.com
}

\begin{abstract}
Resumo: A questão de a tradução ser reconhecida como arte é tema desconsiderado pelo grande público consumidor de tradução. Assim, este artigo pretende confrontar algumas ideias vigentes sobre tradução compiladas através de uma pesquisa de campo. Para tal, baseia-se na visão funcionalista proposta por Nord (1991), nos olhares teóricos de Bassnett (2005) e de Sobral (2008) sobre o processo tradutório e nos pensamentos de Paz (1971), Silveira (1954), Tavares (1994) e Rónai (1981). Com a voz do leitor e dos autores, pretende promover a reflexão e a reavaliação de conceitos, evidenciando ao público leigo toda a complexidade e o processo artístico presente no ato de traduzir.
\end{abstract}

Palavras-chave: Tradução; Processo Artístico da Tradução; Questão Cultural; Habilidade do Tradutor.

Abstract: The issue of translation to be recognized as art is not something considered by the general public consumer of translation. Therefore, this article intends to discuss some current ideas on translation, confirmed by a field survey. To accomplish that, the article goes through the process of translation based on Nord's functionalist view and on the theoretical eyes of Bassnett (2005) and Sobral (2008) on this process. It also relies on the thoughts of Paz (1971), (Silveira), Tavares (1994) and Rónai (1981) about translation. By showing these studies it intends to promote the reflection and reevaluation of concepts, showing the reader all the complexity and the artistic process that is present in the act of translation.

Keywords: Cultural Issue; The Artistic Process of Translation; Translation; Translator's Ability.

\section{Introdução}

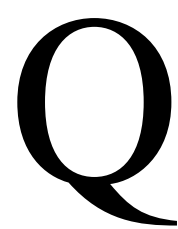

uase nunca se enxerga a tradução como arte. Porém, a tradução de uma obra literária, assim como a obra, também é uma arte, ou pelo menos deveria ser. Lourenço Filho (1954), quando escreveu o prefácio da obra A arte de traduzir (SILVEIRA, 1954, p. 5), afirmou que a atividade de traduzir assume a feição de arte, porque, além de execução técnica, necessita de um senso criador.

Nessa arte complexa e desafiadora, é admirável o papel que o tradutor desempenha na comunicação entre os povos. O trabalho do tradutor é de grande importância. A maioria das informações que chega até o leitor se baseia no que o tradutor escreve, na "pressuposição de que ele traduz o que foi dito ou escrito em língua estrangeira" (SILVEIRA, 1954, p. 9). Basta então que se reflita sobre isso, para que se perceba a tremenda responsabilidade moral e intelectual que recai sobre o tradutor. No entanto, a maioria das pessoas parece não ter ideia 
do que é, verdadeiramente, o trabalho do tradutor. Essa arte, assim, ainda permanece invisível aos olhos do grande público e de muitos desavisados que se arriscam a exercitá-la sem realmente conhecê-la.

Com o intuito de comprovar o prestígio do tradutor e o conceito de tradução nutrido pelo público em geral, uma pesquisa de campo foi realizada ao longo de dez dias, em diferentes locais: PUCRS, Livraria Cultura (Porto Alegre-RS) e rede social Facebook. Foram entrevistadas 100 pessoas, entre estudantes e profissionais de diferentes áreas, com idades de 18 a 75 anos, moradores das cidades de Porto Alegre-RS e Viamão-RS. É importante destacar que nenhum dos entrevistados é profissional da área de tradução. Tal pesquisa resume-se em 5 perguntas, respondidas na ordem: 1) Qual é o seu conceito de arte? 2) Para você, o que é traduzir? 3) Quando você compra uma obra literária - não brasileira -, você olha somente o título e o autor da obra, ou você observa também quem é o tradutor ou tradutores do livro? 4) Quando você lê uma obra literária - estrangeira -, você presta atenção somente no título e no autor da obra, ou se interessa em saber quem é o tradutor/tradutores do livro? 5) Alguma vez você já buscou uma obra literária estrangeira, traduzida por algum tradutor específico?

164 De acordo com os resultados gerais da pesquisa, o conceito de arte nutrido pelo público parece ser seguro e uníssono. A palavra "arte", do latim ars - técnica e/ou habilidade -, designa atividades que têm características criativas e estéticas, um conceito comum também na bibliografia especializada. As palavras mais utilizadas pelos entrevistados nesse conceito foram: expressão, criatividade, manifestação, sentimento e beleza; também foram citados alguns tipos de arte, como artes plásticas, quadros, música, esculturas etc. Foi enfatizado por grande parte do público a ideia de que arte é um sentimento subjetivo, ou seja, de que um objeto só é arte a partir do sentimento que ele provoca. Com base nessa definição, aparentemente já inserida em nossa cultura, percebe-se do público entrevistado uma clara visão do que arte representa para cada um - o criativo, o belo, o especial, uma representação criativa de algo maior.

Porém, como podemos ver no Quadro 1, a seguir, nenhum dos entrevistados $(0 \%)$ mencionou alguma habilidade artística ao seu conceito de tradução, mesmo quando explicitado que se tratava de tradução literária. 
Quadro 1: Conceito de tradução do público entrevistado.

\begin{tabular}{|c|l|}
\hline Total & \multicolumn{1}{|c|}{ Respostas do público } \\
\hline $46 \%$ & Conceito literal de tradução, como passar um texto de uma língua para outra. \\
\hline $13 \%$ & Conceito de tradução como interpretação. \\
\hline $9 \%$ & Conceito de tradução como explicar ou fazer entender. \\
\hline $7 \%$ & Conceito de tradução como transferência ou garantia de significado. \\
\hline $3 \%$ & $\begin{array}{l}\text { Menciona a palavra "cultura" ou o conhecimento cultural como parte do seu } \\
\text { conceito de tradução. }\end{array}$ \\
\hline $\mathbf{2 2 \%} \%$ & $\begin{array}{l}\text { Menciona alguma ideia de habilidade artística ao seu conceito de tradução. } \\
\mathbf{1 0 0 \%}\end{array}$ \\
\hline
\end{tabular}

Fonte: A autora (2013).

O conceito mais popular de tradução, de acordo com a pesquisa realizada, é "passar um texto de uma língua para outra" (43\% dos entrevistados), ou seja, transferir um texto da língua-fonte (LF) para a língua-meta (LM). Com base nessa definição, a ideia de que cada palavra na língua-fonte equivale a uma palavra na língua-meta não é rara de se encontrar. Em segundo e terceiro lugar, os conceitos mencionados com maior frequência pelos entrevistados foram interpretação (13\%) e fazer entender (9\%). É relevante ressaltar que outras definições do latim traducere, como revelar, representar, simbolizar e ser o reflexo de, não foram mencionadas. Em relação à palavra "cultura", apenas três entrevistados a mencionaram como conceito de tradução. Na Livraria Cultura, um dos locais da entrevista, uma definição muito ligada aos estudos da tradução, porém negativa a respeito, foi sugerida por um estudante de Psicologia, ele respondeu a pergunta número 2 com a famosa frase italiana: "traduttore, traditore", ou seja, "tradutor, traidor". Assim como ele, outros entrevistados mencionaram a palavra "fidelidade" como parte do conceito.

Como resultado desses conceitos, qual a porcentagem da população que se interessa pela identidade do tradutor da obra que estão lendo? Quem busca em uma determinada obra mundial o seu tradutor preferido? Quem é capaz de ver o tradutor também como um escritor? De acordo com os resultados da pesquisa (Quadro 2), 79\% dos entrevistados admitiram nunca haver manifestado interesse algum pelos tradutores das obras literárias que consomem. 
Quadro 2: Interesse do público entrevistado pelo tradutor das obras que consomem.

\begin{tabular}{|c|c|}
\hline Total & Respostas do público \\
\hline $79 \%$ & Nunca manifestou interesse pelos tradutores das obras que consome. \\
\hline $6 \%$ & $\begin{array}{l}\text { Já se interessou, alguma vez, pelos tradutores das obras literárias que comprou ou } \\
\text { leu. }\end{array}$ \\
\hline $3 \%$ & $\begin{array}{l}\text { Interessa-se pelo tradutor somente quando a capa da obra chama a atenção para o } \\
\text { tradutor. }\end{array}$ \\
\hline $1 \%$ & Já buscou uma obra traduzida por um tradutor em específico. \\
\hline $4 \%$ & $\begin{array}{l}\text { Buscou um tradutor específico em uma obra quando exigido para trabalho } \\
\text { acadêmico. }\end{array}$ \\
\hline $2 \%$ & $\begin{array}{l}\text { Interessa-se por traduções “mais fiéis", e para isso, busca o nome de editoras, não } \\
\text { tradutores, como garantia de melhor tradução. }\end{array}$ \\
\hline $5 \%$ & $\begin{array}{l}\text { Interessa-se pelos tradutores, sob uma visão negativa do tradutor; generaliza a } \\
\text { maioria dos profissionais como não confiáveis, ou a comunicação da tradução } \\
\text { como não confiável, em sua maioria. }\end{array}$ \\
\hline $100 \%$ & Total de 100 pessoas entrevistadas \\
\hline
\end{tabular}

Fonte: A autora (2013).

É a partir dos conceitos mais gerais demonstrados na pesquisa, da voz desse público, que eu convido o leitor deste artigo a dialogar. O que está inserido no processo de tradução? Será possível restringir esse processo a um mero uso de equivalências lexicais? Se o ato de traduzir fosse simples, como descreve o conceito geral do público entrevistado, todos os problemas linguísticos estariam descartados e talvez não precisássemos dos estudos de tradução introduzidos no final da década de 1970, a não ser que esses estudos viessem para contrariar essa ideia.

Este diálogo baseia-se na visão funcionalista de Christiane Nord (1991), em que a tradução é vista como um processo intercultural, que estabelece interações entre culturas via linguagem, interações que dependem, sobretudo, de quem diz o quê a quem, onde e como. Fundamenta-se em uma perspectiva cultural, abordada tanto por Eco (2007) quanto por Bassnett (2005) e Sobral (2008), sobre a visão da tradução como um processo criativo, comprovada também pelos estudos de Silveira (1954) e Paz (1971). Para contribuir, proponho ainda um olhar para a tradução sob a perspectiva hermenêutica, considerando a arte da interpretação proposta por Schleiermacher (c.1805-1833/1999). 
Com base nos resultados da pesquisa, é possível inferir que talvez estejamos ainda engatinhando nos estudos da tradução, apesar de toda a revalorização que já se conquistou nessa área. Isso com base na visão que o público em geral demonstra ter sobre tradução, mesmo literária, na invisibilidade do tradutor e na constatação de que a maioria dos cursos de especialização nessa área é relativamente recente no Brasil. A USP intensificou seus estudos de pós-graduação nessa área nos anos 1990; a PUCRS, em 2012, foi a primeira universidade no Estado do Rio Grande do Sul a oferecer um curso de pós-graduação em tradução. De acordo com o SINTRA (Sindicato Nacional dos Tradutores), a profissão de tradutor ou intérprete não é "regulamentada" no Brasil, o que significa, na prática, que qualquer um pode exercê-la.

Esse, provavelmente, seja o motivo pelo qual, nos dias de hoje, ainda encontramos pessoas letradas, universitários e profissionais de diversas áreas que veem a tradução como um processo mecânico. Que acreditam ser essa uma habilidade que compete a qualquer indivíduo com conhecimentos básicos de um par de línguas, sua língua materna e uma estrangeira. Assim, o conceito de arte descrito pelo público, a quem este artigo é direcionado, passa longe da ideia que muitos fazem sobre o que é traduzir.

É muito comum ouvir, quando se tem algum conhecimento bilíngue, pedidos como: "Traduz aí o que diz a canção" - um pedido de tradução simultânea (especialidade da tradução que requer muito estudo, prática e uma habilidade que os intérpretes de conferência possuem: a de ouvir e falar ao mesmo tempo) -, ou "Traduz esse texto para mim, tenho 15 minutos, pode ser?". Esses exemplos permitem entender que tradução é simplesmente um ato de transcrever léxicos, mecanicamente, de uma língua a outra, uma fórmula matemática, em que, ao invés de números, usam-se léxicos: léxico x equivale a léxico y. Simples assim!

Ao estudarmos um pouco sobre tradução, descobrimos que de fato o raciocínio simplista, que restringe a tradução a uma troca de expressões equivalentes de uma língua para outra e nega o trabalho artístico e criativo desse profissional de línguas, já foi opinião de muitos teóricos, principalmente no século XIX. Apesar de toda a revalorização conquistada pela tradução, de alguma forma ainda hoje esse raciocínio que desvaloriza o tradutor está enraizado em nossa cultura.

Como demonstra a pesquisa (Quadro 2), apenas 21\% dos entrevistados se interessaram alguma vez pelos tradutores dos livros que consomem, sendo que muitos deles nutriam uma imagem negativa dos tradutores em geral. É possível que os tradutores profissionais realmente não esperem ser reconhecidos por algum público que não o dos Estudos da Tradução, ou dos 
Estudos Literários. Talvez o fato de estarem invisíveis os faça sentir que cumpriram o seu papel, de aproximar leitor e obra, trazer a voz do autor ao novo leitor. E isso talvez seja o suficiente para os tradutores experientes. Uma profissão de doação. Só que nessa invisibilidade procriam-se subtradutores, pessoas sem pendor artístico e muitas vezes sem o conhecimento linguístico necessário, que se aventuram nessa arte. O que acaba por deturpar ainda mais a imagem do tradutor. Essas pessoas não são culpadas, mas requisitadas, exigidas por nossa sociedade, que também não possui o conhecimento necessário sobre o assunto, sobre o que é traduzir.

Não será possível perceber a tradução literária como arte se essa arte não for reconhecida publicamente. Ao divulgar essa arte, tornamos os estudos em tradução, de certa maneira, mais acessíveis ao grande público, o que contribui para a valorização e para a evolução dos estudos da tradução.

Para os que não concordam com o termo "arte", perguntamos: o que caracteriza um objeto como arte? Como afirmar a tradução literária como arte ou não arte, se o que conceitua arte de não arte, ao menos publicamente, é o seu grau de aparência e qualidade, sendo que 168 tanto aparência como qualidade é uma ideia subjetiva, um sentimento imediato entre um sujeito e uma obra de arte? Como será possível identificar ou reconhecer no objeto (tradução) a arte, sem que se tenha a possibilidade de conhecer, reconhecer ou visualizar o objeto? Assim, descrever o processo tradutório para o grande público é o objetivo deste artigo. Descrevemos aqui os pressupostos fundamentais, para que se veja o ato de traduzir como um processo artístico. Dessa forma, o leitor deste artigo pode escolher enxergar a tradução como arte, ou não.

\section{Habilidade criativa necessária}

É de conhecimento básico dos estudos da tradução que

[...] o conhecimento de duas línguas em suas várias modalidades não assegura a capacidade de traduzir, porque esta é uma habilidade específica [...] há um 'pensamento de tradutor', uma dada maneira de ver as línguas e suas inter-relações, que envolve elementos que somente a posição do tradutor permite ver (SOBRAL, 2005, p. 19).

Os estudos de Sobral (2005) confirmam que tradução literária é muito mais um processo criativo do que mecânico, ao contrário do que muitos pensam, ou demonstram acreditar. Segundo esse autor (2008, p. 70): 
Traduzir é mobilizar um texto por meio de outro discurso, e o tradutor, ao dirigir-se a um público a que o autor não pode se dirigir cria necessariamente novas relações enunciativas, discursivas, uma nova relação entre o autor e o público, ou mesmo cria uma imagem do autor na língua-alvo por meio da criação de um discurso em uma língua estrangeira a que o autor também não tem acesso como autor.

A necessidade de se criar novos discursos na tradução comprova-se pelo fato, salientado por Rónai (1981, p. 34) de que "Ainda que dois vocábulos de duas línguas sejam definidos de maneira igual, os enunciados de que eles podem fazer parte não são os mesmos, nem as conotações que evocam serão iguais”. Rónai (1981) nos diz que, para traduzir o texto original, o tradutor deve esquecer momentaneamente as palavras utilizadas na língua-fonte para que o discurso seja recriado na língua-meta. Porém, ele afirma que, na poesia, a escolha das palavras e a apresentação do texto podem fazer parte da comunicação.

A sonoridade e o acento dos vocábulos, o seu aspecto visual, a harmonia das rimas, o comprimento e o ritmo dos versos, a composição das estrofes, tudo isso é conteúdo e forma ao mesmo tempo e, portanto o tradutor tem de guardá-los presentes ao espírito enquanto recria o poema em seu idioma. Mas quanto mais invencível parece, tanto mais a dificuldade espicaça o artista (RÓNAI, 1981, p. 129).

Muitos autores contemporâneos concordam que, por esse motivo, a tradução poética é a que mais desafia e exige a criatividade do tradutor. Sendo assim, traduzir discursos nunca será uma fórmula matemática; pois a não ser que estejamos nos referindo à tradução de termos científicos, quando lidamos com palavras ou com arte, não existe uma resposta exata, nem mesmo uma única possibilidade de interpretação. Isso pode ser comprovado pelo fato de existirem diferentes traduções de uma mesma obra poética. Poderá haver traduções diferentes de uma única obra e muitas delas serem consideradas boas, ou ótimas. Como há para o poema "The Raven", de Edgar Allan Poe, por exemplo. Além de outras boas traduções, tanto Machado de Assis quanto Fernando Pessoa foram excelentes tradutores dessa obra e, ainda assim, suas traduções diferem uma da outra. Vejamos o início do poema original em inglês, uma tradução literal, sem análises culturais ou pendor artístico, e as traduções de Fernando Pessoa e de Machado de Assis (ALVES, s/d).

\section{The Raven}

By Edgar Allan Poe

Once upon a midnight dreary, while I pondered, weak and weary, Over many a quaint and curious volume of forgotten lore - 
While I nodded, nearly napping, suddenly there came a tapping,

As of some one gently rapping, rapping at my chamber door.

"'Tis some visiter," I muttered, "tapping at my chamber door Only this and nothing more."

Ah, distinctly I remember it was in the bleak December;

And each separate dying ember wrought its ghost upon the floor.

Eagerly I wished the morrow; - vainly I had sought to borrow

From my books surcease of sorrow-sorrow for the lost Lenore-

For the rare and radiant maiden whom the angels name Lenore-

Nameless here for evermore.

\section{O Corvo}

(Tradução literal feita pela autora)

Em uma meia-noite melancólica, enquanto eu ponderava fraco e cansado,

Sobre muitos curiosos volumes de esquecida doutrina

Enquanto eu cabeceei, quase cochilando, de repente veio um toque,

Como se de alguém batendo suavemente, batendo na porta do meu quarto.

“"É algum visitante", eu murmurei, "batendo à porta do meu quarto

Só isso e nada mais."

Ah, claramente eu me lembro, foi no frio dezembro;

E cada brasa separada morrendo forjou seu fantasma sobre o chão.

170 Ansiosamente desejei o dia de amanhã; - em vão eu tinha procurado pegar emprestado dos meus livros o cessar da tristeza, tristeza pela perdida Lenore

Pela preciosa e radiante donzela a qual os anjos chamam Lenore

Sem nome aqui para sempre.

\section{O Corvo}

\section{(Tradução de Fernando Pessoa)}

Numa meia-noite agreste, quando eu lia, lento e triste,

Vagos, curiosos tomos de ciências ancestrais,

E já quase adormecia, ouvi o que parecia

O som de alguém que batia levemente a meus umbrais.

"Uma visita", eu me disse, "está batendo a meus umbrais.

É só isto, e nada mais."

Ah, que bem disso me lembro! Era no frio dezembro,

E o fogo, morrendo negro, urdia sombras desiguais.

Como eu qu'ria a madrugada, toda a noite aos livros dada

P'ra esquecer (em vão!) a amada, hoje entre hostes celestiais -

Essa cujo nome sabem as hostes celestiais,

Mas sem nome aqui jamais!

\section{O Corvo}

(Tradução de Machado de Assis)

Em certo dia, à hora

Da meia-noite que apavora, 
Eu, caindo de sono e exausto de fadiga,

Ao pé de muita lauda antiga,

De uma velha doutrina agora morta,

Ia pensando, quando ouvi à porta

Do meu quarto um soar devagarzinho,

E disse estas palavras tais:

"É alguém que me bate à porta de mansinho;

"Há de ser isso e nada mais".

Ah! Bem me lembro! Bem me lembro!

Era no glacial dezembro;

Cada brasa do lar sobre o chão refletia

A sua última agonia.

$\mathrm{Eu}$, ansioso pelo Sol, buscava

Sacar daqueles livros que estudava

Repouso (em vão!) à dor esmagadora

Destas saudades imortais

Pela que ora nos céus anjos chamam Lenora

E que ninguém chamará mais.

É possível perceber que tanto Fernando Pessoa quanto Machado de Assis manifestam sua interpretação pessoal do poema, da voz do autor, e ao mesmo tempo em que traduzem sua interpretação prezam pela cena escura de dor e pela sonoridade manifestada no poema em língua inglesa. Ambos os autores criam assim um lindo poema na língua portuguesa, que são traduções do poema de Edgar Allan Poe: comunicam o mesmo, porém, de forma diversa. Se pensarmos na tradução como a representação de uma ideia, é possível pensar em diferentes representações dessa ideia, a mais cabível ou "fiel” ao poema, no entanto, será uma escolha pessoal, desde que essa representação tenha interpretado a obra, e que essa tradução seja possível como representante também da língua para a qual foi traduzida. Assim como a música, que recebe intérpretes e com eles revive, as obras recebem os tradutores, e assim a comunicação, a arte e a oportunidade da obra de ser revivida são disseminadas.

"Na Natureza nada se perde, nada se cria, tudo se transforma", essa famosa frase atribuída a Lavoisier (1743-1794) é um princípio da química e nos diz que nada é novo, nada vai embora, mas tudo toma aspectos diferentes. Não poderia ser diferente com a arte, com a literatura e muito menos com a tradução. A tradução é uma arte pelo fato de que toda arte é em si uma tradução. $O$ artista plástico que vê a cena e a traduz em um quadro utiliza determinada técnica para transformar a cena em uma obra de arte; assim como o fotógrafo, que capta o momento ou o sentimento e o traduz para a fotografia. A dança, por exemplo, é a tradução de um sentimento evocado pela música; a música é a própria tradução de sentimentos em notas musicais e letras. A literatura é uma arte, pela habilidade do autor de 
usar as palavras, de usar a sua língua materna para traduzir em palavras a sua imaginação, e aquilo que pretende comunicar. A tradução literária é uma arte pela habilidade do tradutor em trabalhar com diferentes línguas, interpretar e conhecer tão profundamente o texto, a ponto de descobrir recursos na língua que lhe garantam a possibilidade de transformar o discurso em língua-fonte em um discurso em língua-meta para uma nova cultura. Se toda arte é uma tradução, por que traduzir não seria uma arte?

\section{A questão cultural}

Perceber a tradução sob uma perspectiva cultural é indispensável para que se reconheça o processo criativo presente no modo como o tradutor opera diferentes línguas. Já dizia Saramago (apud Zilly1): “Os autores escrevem as suas respectivas literaturas nacionais, mas a literatura mundial, essa é obra dos Tradutores!”. Por que quase ninguém percebe o trabalho criativo que o tradutor executou ao fazer reviver a criatividade do autor em um mundo diferente?

A resposta para essa pergunta, que também serve de explicação para os resultados da 172 pesquisa, pode estar no fato de que muitas pessoas não percebem que a grandeza do trabalho do tradutor está em operar línguas. Já se sabe que a língua é a identidade de um povo, um elemento vivo, dinâmico, carregado de particularidades culturais. Como nos diz Saussure (1968, apud CARVALHO, 2003, p. 57), “A linguagem tem um lado individual e um lado social, sendo impossível conceber um sem o outro". Silvio Elias (1978, apud CARVALHO, 2003, p. 88) acrescenta: "Convém ainda observar que um estado de língua não é necessariamente sincrônico (ou seja, estático). Num estado de língua coexistem formas atuais (sincrônicas), formas que vão caindo em desuso e formas em estado nascente". Podemos reforçar esse conhecimento com a definição de Celso Cunha e Lindley Cintra (2001, p. 1):

\footnotetext{
Língua é um sistema gramatical pertencente a um grupo de indivíduos. Expressão da consciência de uma coletividade, a língua é o meio por que ela concebe o mundo que a cerca e sobre ele age. Utilização social da faculdade da linguagem, criação da sociedade, não pode ser imutável; ao contrário, tem de viver em perpétua evolução, paralela à do organismo social que a criou.
}

Partindo do fato de que, ao traduzir, o tradutor opera com duas línguas distintas e, portanto, sociedades distintas, diferentes modos de pensar, culturas diferentes, é possível

\footnotetext{
${ }^{1}$ Conforme palestra realizada na PGET (Pós-Graduação em Estudos da Tradução) da Universidade Federal de Santa Catarina (UFSC) em 2013.
} 
perceber que, normalmente, não haverá equivalência linguística completa em tradução. Sobral (2008, p. 81) explica a impossibilidade de se trabalhar línguas diferentes por equivalências lexicais: “[...] A impossibilidade de trabalhar estritamente com equivalências ocorre porque cada língua, ainda que tenha semelhanças com as outras, difere delas porque surge e se desenvolve num dado contexto social e histórico que não tem equivalência em outros contextos".

Zilly (2013), professor e tradutor alemão que traduziu o clássico Os Sertões de Euclides da Cunha e prepara para este ano uma nova tradução para o alemão da obra Grande Sertão: Veredas, de Guimarães Rosa, diz em entrevista para a revista Língua Portuguesa que "nenhuma língua, nenhum elemento de uma língua expressa totalmente as mesmas ideias, sensações, associações, imagens etc.” (p. 11). O que pode haver, segundo o tradutor, são "equivalências de efeito em termos de ideias, imaginações, sensações, imagens, impressão sonora, ótica" (2013, p. 12). Ele coloca como exemplo a palavra "saudade", que algumas vezes significa uma dor causada pelo desejo de alguém, algo ou um passado, mas que, ao menos teoricamente, é recuperável; outras vezes, é uma dor causada pela perda irrecuperável, através da morte de alguém querido, por exemplo. No entanto, esse duplo sentido, do ponto de vista da língua alemã, é estranho, pois, para essa língua, os dois tipos de dor são distintos, existindo, portanto, palavras distintas para se referir a elas. Zilly (2013) fala ainda que, quando encontra uma sequência de palavras meio enigmática, que nem mesmo suas consultas são capazes de resolver, utiliza a tradução palavra por palavra, no objetivo de transpor a máxima quantidade e qualidade de significados, dando ao leitor a autonomia para escolher algum significado, dentro da massa de significados possíveis naquele idioma.

Duas línguas não são nunca suficientemente semelhantes para serem consideradas como representantes da mesma realidade social. Os mundos nos quais as diferentes sociedades vivem são mundos distintos, e não simplesmente o mesmo mundo com rótulos diferentes (SAPIR, 1956, apud BASSNET, 2005, p. 35).

Bassnett (2005) também é elucidativa ao ponderar que para traduzir não é necessário "apenas" conhecer a cultura da língua-meta. Conhecer a cultura da língua-fonte é essencial para a interpretação do texto-fonte.

\footnotetext{
A língua, portanto, é o coração do corpo da cultura, é a interação entre os dois que resulta na continuação da energia-vida (life-energy). Do mesmo modo que o cirurgião, ao operar o coração, o tradutor correrá risco se tratar o texto isoladamente da cultura (BASSNETT 2005, p. 36).
} 
Em Silveira (1954), lemos ainda que a complexidade de se trabalhar com línguas não se encontra somente no idioma ou nos dialetos, mas também na fala - a linguagem individual de cada um.

\begin{abstract}
Essa diferença é universalmente reconhecida. [...] Em outras palavras, "língua" quer dizer linguagem coletiva; e "fala", linguagem individual. [...] Quando um grupo de indivíduos, ou uma pequena parte da coletividade linguística fala mais ou menos de modo semelhante, mas que se afasta dos padrões estabelecidos e aceitos pela "grande comunidade linguística", costuma-se dizer que tais indivíduos se exprimem em "dialeto". Mas nem mesmo dentro do padrão estabelecido e aceito como "língua" ou "idioma" de um povo ou país, os indivíduos não falam nem escrevem a sua língua materna de maneira idêntica (SILVEIRA, 1954, p. 34).
\end{abstract}

\title{
4. A arte de interpretar
}

Traduzir não se contém na operação elementar da busca por correspondência dos vocábulos. Arte muito mais complexa e sutil deverá harmonizar aquelas duas outras, já de si tão delicadas, a de ler e a de escrever (SILVEIRA, 1954, p. 15).

A criação de novos discursos que comprovam o processo artístico presente na tradução 174 se dá, principalmente, pela questão cultural da língua e pela questão individual, a fala linguagem individual.

O tradutor desconstrói o modo de ser do discurso em língua estrangeira e o reconstrói noutra língua, e, assim, cria outra obra que é parte de um discurso em língua estrangeira, nem por isso é menos discurso na língua em que veio a existir pelas mãos do tradutor (SOBRAL, 2008, p. 73).

A criação de novos discursos para dizer "o mesmo" só é possível através de um trabalho meticuloso do objeto textual: o tradutor deve estudar sobre o autor, os aspectos culturais que envolvem o texto, interpretar a história presente no texto, as personagens e os diálogos.

Sobral (2008) concorda que o tradutor em ação enfrenta todo um processo de interpretação e conhecimento, ou apropriamento do discurso, para só então vislumbrar o problema da seleção de uma expressão ideal na língua-meta, para o seu leitor-alvo.

O discurso vem a existir fundamentalmente por meio de um processo de produção de sentidos realizado por, para e entre sujeitos. Logo, como não se pode entender o discurso sem entender seus sujeitos (ou protagonistas), uma definição de discurso que não envolva uma definição dos sujeitos discursivos e que não leve em conta seu ser sócio-histórico concreto e sua constituição no próprio discurso é incompleta (SOBRAL, 2008, p. 59). 
Afirma ainda que "Pode-se, legitimamente, considerar que todo ato de tradução é tanto tradução como interpretação, porque traduzir é sempre interpretar e porque sempre que se interpreta se traduz" (SOBRAL, 2008, p. 88).

O processo de interpretação e compreensão de textos e discursos, de forma geral, é descrito como arte na hermenêutica de Schleiermacher (c.1805-1833/1999). Nesse olhar, a compreensão é realizada principalmente através de dois procedimentos complementares: a interpretação gramatical e a subjetiva. No autor e na linguagem estão os pressupostos fundamentais da existência de qualquer texto ou discurso. Em outras palavras: o discurso textual é o objeto a ser interpretado e através dele também o autor, em seu estilo e originalidade. Segundo a filosofia hermenêutica, a partir da compreensão da linguagem e do autor, poderá tentar-se se alcançar a melhor compreensão possível do texto.

Para Rónai (1981, p. 31):

Na realidade a tradução é o melhor e, talvez, o único exercício realmente eficaz para nos fazer penetrar na intimidade de um grande espírito. Ela nos obriga a esquadrinhar atentamente o sentido de cada frase, a investigar por miúdo a função de cada palavra, em suma a reconstituir a paisagem mental do nosso autor e a descobrir-lhes as intenções mais veladas.

Mesmo que hoje não se acredite mais na possibilidade de se conhecer um autor a partir de sua obra, o fato é que interpretar legitimamente o discurso de um texto é uma arte, e não uma tarefa fácil. Como negar o processo artístico que envolve o tradutor quando ele deve lidar com a complexidade cultural de dois públicos diferentes e com a individualidade do autor, para interpretar e comunicar um discurso em línguas diferentes? Zilly (2013), quando questionado se toda tradução é possível de acontecer, responde que "essa é uma questão importante não só da tradução, mas de toda a hermenêutica e toda a teoria da comunicação" (p. 11). Afirma ainda que: "Em toda comunicação, há um resto daquilo que não é entendido, é mal-entendido, se perde e, mesmo assim, a comunicação funciona" (p. 11). E explica que "há mil maneiras de entender uma frase, diferentemente da intenção do falante. É assim na tradução também” (p. 11).

Por isso, "apropriar-se" do texto-fonte pode ser complexo e até impossível para o tradutor, mas essa tentativa é fundamental, para que ele possa comunicar com segurança "o mesmo" no diverso. Traduzir é interpretar! A tradução opera em nível mais profundo do que a 
simples leitura, pois age sob um trabalho de investigação muito mais meticulosa do objeto textual. Assim, o texto traduzido pode revelar ao leitor muitas riquezas do texto original.

Para realizar o processo de tradução, o tradutor conta muito com sua criatividade, seu conhecimento de mundo, das línguas e sua habilidade para operá-las, sua visão de tradutor e, como não dizer, sua imaginação e sua criatividade em criar discursos na língua-alvo. Afirma Sobral (2008, p. 8) que

todo o ato de tradução envolve uma atividade de leitura de um texto numa dada língua que difere da leitura em geral porque é feita do ponto de vista de um profissional que, em vez de apenas entender o que lê ou responder/reagir ao que lê, deve enunciá-lo para outros interlocutores, tem de reconstituir/reconstruir/restituir o que lê em outra língua, e que, portanto, tem de penetrar em dois universos de discurso e colocá-los numa relação de interlocução, constituindo-se num mediador entre o autor do texto, que se dirige a um dado público que conhece, e o público do texto traduzido, ao qual o autor não pode dirigir-se diretamente.

Portanto, na arte de compreender e interpretar discursos, no fator cultural, na impossibilidade de se trabalhar com equivalências e na habilidade técnica e criativa de recriar uma obra de arte estão os pressupostos fundamentais para que se reconheça o processo artístico da tradução literária.

\section{O papel do tradutor}

Octavio Paz (1971 apud BASSNETT, 2005, p. 16) tem uma bela definição ao diferenciar as tarefas de escritor e tradutor: "o escritor tem a opção de fixar as palavras em uma forma ideal e inalterável, o tradutor tem como tarefa, liberar estas palavras dos limites de sua língua-fonte e permitir-lhes viver de novo na língua para a qual são traduzidas”.

Sobral (2008, p. 118) também descreve o papel do tradutor: "ao ler como leitor, como tradutor e como autor (ou 'outro' autor, se preferir), o tradutor lê o dito e o modo de dizer e os recria na outra língua".

Nas palavras desses autores, compreende-se que o processo de tradução literária é muito mais criativo do que mecânico. Se analisarmos o papel do tradutor descrito pelos autores, o processo complexo e especialmente criativo que envolve o ato de traduzir/recriar, poderemos perceber o tradutor como um coautor do texto que traduz.

O tradutor tem assim uma tarefa de escrita/fala/sinalização que envolve uma dupla ação: a de colocar-se como interlocutor do autor traduzido e a de autor, ou coautor, do texto da tradução, constituindo para isso interlocutores na língua para a qual traduz [...] isso coloca o tradutor numa posição que não é só a de um leitor, ou a de 
um autor, mas de quem é ao mesmo tempo leitor e autor, só que em línguas

diferentes! (SOBRAL, 2008, p. 8).

Se pensarmos ainda sobre a tradução de textos específicos, encontramos no tradutor também a tarefa de pesquisador árduo, pois, principalmente em tradução de textos não literários, conhecer o assunto em pauta é de fundamental importância. Por mais que se conheça muito bem as línguas-fonte e meta, se não se conhece um assunto em língua materna, como se pode escrever sobre esse assunto em outra língua?

Porém, textos não científicos são igualmente complexos e demandam, sim, muita pesquisa. Tradutores ficam à mercê do conhecimento de mundo dos autores e de suas histórias, personagens e enredos. Dessa forma, a pesquisa terminológica tende a ser uma constante. Em um romance de suspense que se passa em Londres, por exemplo, descrever com detalhes o sistema de metrôs e traduzir expressões comuns ao seu uso pode ser essencial para a história. Se a tradução for de um romance épico, com certeza o vocabulário pode demandar ainda mais pesquisa. Se uma das personagens da obra for um arquiteto, muito provavelmente termos específicos de arquitetura devem aparecer. Assim, o conhecimento específico do autor estará presente em cada cuidadosa escolha de palavras que ele fizer. $\mathrm{O}$ tradutor deve lidar com as inferências presentes no texto, com o intertexto. $\mathrm{O}$ tradutor deve "dançar conforme a música", mesmo que as barreiras culturais insistam em pará-lo. Deve ter ainda mais criatividade e flexibilidade na resolução de problemas, mantendo os implícitos presentes no discurso, ou melhor, fazer reviver os implícitos. Reviver o humor, a ironia, o suspense, o jogo de palavras, a malandragem, a poesia, reviver a arte em uma nova cultura.

\section{Tradutor - autor para outro leitor}

A complexidade da tradução literária vai além das questões descritas neste artigo. É importante perceber que tradutores têm elementos vivos e dinâmicos de trabalho - línguas, elemento carregado de crenças, de enorme bagagem cultural. $\mathrm{O}$ tradutor deve dirigir-se a um público diferente do público do texto original. Susan Bassnett (2005) também fala sobre expressões intraduzíveis e sobre a tradução de expressões idiomáticas que, assim como os trocadilhos, só tem sentido em certa cultura. “[...] como a língua é o sistema modelador primário dentro de uma cultura, a intraduzibilidade cultural tem que estar de fato implícita em qualquer processo tradutório" (BASSNETT, 2005, p. 56).

Seguindo a visão funcionalista da tradução, Sobral (2008) afirma que a tradução deve ser dirigida ao novo leitor e, por isso, não pode se restringir a equivalências, deve buscar 
correspondências dinâmicas entre formas de expressão, ou seja, buscar maneiras de dizer a mesma coisa em outra língua. Esse autor enfatiza que essas maneiras devem variar de acordo com o público, a época, o lugar, o propósito de tradução, tipo de texto, tipo de discurso e quantas outras informações se façam necessárias, para que se crie esse novo texto para o novo leitor.

\begin{abstract}
Pensar a interpretação como a busca de correspondências - com maior ou menor sucesso - entre os sentidos criados numa língua e as possibilidades de criação de sentido em outra língua - em vez de equivalências entre elementos isolados ou textos, frases etc. - implica pensar as línguas não como compostas por elementos equivalentes aos de outras línguas, mas como compostas por formas de expressão que usam esses elementos para criar, no âmbito de uma dada cultura, formada por diferentes expressões, sentidos que a operação de tradução pode fazer corresponder a sentidos criados em outra cultura, igualmente complexa, formas de expressão que não são exatamente iguais nem equivalentes, mas que permitem criar efeitos de sentido semelhantes (SOBRAL, 2008, p. 81).
\end{abstract}

Bassnett (2005, p. 45) também segue a linha funcionalista ao afirmar:

Tentar impor o sistema de valor da cultura da língua-fonte para a cultura da línguameta é perigoso, e o tradutor não deve ser tentado pela escola que tem pretensões de determinar intenções originais de um autor com base em um texto autocontido. $\mathrm{O}$ tradutor não pode ser o autor do texto em língua-fonte, mas, como ator do texto em língua-meta, tem uma clara responsabilidade para com os leitores de LM.

Ao ler uma obra traduzida, uma obra pronta para ser devorada em nossa língua materna, quantos de nós são capazes de perceber o trabalho minucioso e artístico que a fez chegar a nós? Durante o processo tradutório, principalmente de uma obra literária, o tradutor é constantemente chamado a fazer escolhas, das mais sutis às mais aparentes: escolher, por exemplo, a melhor tradução de uma expressão intraduzível; escolher entre oferecer uma expressão não correspondente em sentido, mas possível de ser vivida pelo leitor, ou talvez quebrar o ritmo de seu texto, para mais adiante explicar ao seu leitor inserindo uma nota de rodapé; escolher entre estrangeirar o seu leitor, trazendo até ele elementos de outra cultura, ou domesticar o texto do autor de acordo com a cultura do seu leitor. O tradutor lida ao mesmo tempo com as nuances de sua língua e com as de outra língua para só então transcrever a mensagem, e isso tudo sem deixar de considerar o seu receptor. Segundo Eco (2007, p. 50), “o tradutor deve escolher a acepção ou o sentido mais provável e razoável e relevante naquele contexto e naquele mundo possível”. 


\section{Considerações finais}

O tema deste artigo é polêmico, para que se realizasse, foi necessário estruturar uma pesquisa de campo para diagnosticar essas vozes que desvalorizam a arte da tradução e, por consequência, o tradutor. Era previsível que grande parte dessas vozes viria de um público sem conhecimento sobre o assunto, mas ela surge também de uma visão mais tradicional da tradução, e talvez até da arte, uma visão que acredita na perda de identidade de um determinado texto.

Segundo Sobral (2008, p. 122-3), a ideia de perda na tradução não é válida, exatamente porque as línguas se assemelham, mas não são iguais. Se não houvesse semelhanças seriam intraduzíveis, e se não fossem diferentes, não precisariam de tradução. $\mathrm{O}$ que deve ser comunicado na tradução é o discurso, e não o texto. O que fica claro, já que língua é cultura, e não código ou inventário de termos. Sobral (2008, p. 120) nos diz que "Apesar de todo o texto querer ser válido quanto ao mundo em si, verdadeiro quanto a uma possibilidade de entender o mundo e justo em termos de revelar a intencionalidade que mobiliza o autor, não há correspondência entre o mundo e a representação linguística do mundo, mas uma refração, uma “interpretação"”. Ele nos explica que o problema da crítica que insiste na "fidelidade" está na ideia de que há no dito original um sentido fixo essencial que uma tradução teria que reproduzir. Afirma ainda que nem o autor poderia dizer o que é ser fiel ao texto dele, ao menos não sob todos os aspectos, e que a fidelidade só é possível justamente criando-se um texto novo, não totalmente diferente, mas diverso, ou não se estaria traduzindo, mas copiando ou repetindo o dito texto original, o que, segundo esse autor, é impossível de se fazer.

Já Venuti (2004) questiona a noção de autoria de textos. Ele questiona a ideia que se faz de originalidade, uma vez que significados e contexto são determinados por fatores sociais e históricos. Sendo assim, a autenticidade presente no ato de escrever será sempre determinada por questões externas ao autor. Ao questionar a originalidade na autoria de textos, Venuti (2004) chama a atenção para a autoria na tradução. Ele acredita que mediante a impossibilidade de originalidade, autor e tradutor deveriam gozar do mesmo prestígio cada um em sua cultura. Defende ainda que a invisibilidade do tradutor na sociedade se dá, justamente, pela domesticação do texto, ou seja, quanto mais fluente e autêntica a tradução, mais consumível enquanto obra e maior a invisibilidade do tradutor. Este artigo comprova esse fato através da pesquisa, já que o "interesse" pelo tradutor só foi mencionado por entrevistados que mantinham uma visão negativa a respeito de tradutores, e de péssimas 
traduções que haviam lido. Venuti (2004) sugere como proposta de visibilidade ao tradutor, uma tradução estrangeirizadora, ou seja, que adota ideias alheias à cultura-meta. Ele defende que apenas com a intervenção do tradutor manifesta no texto será possível garantir a visibilidade do tradutor ao leitor.

Porém, apoiando-se também no estudo de Benedetti (2003), este artigo vem dizer que a sociedade não enxerga o tradutor porque não conhece realmente o processo de tradução. Portanto, a sociedade não reconhece que o fato de não perceber a interferência tradutória no texto é o que prova a capacidade artística do tradutor em escrever para um novo leitor, e consequentemente sua maior visibilidade como produtor textual.

O diálogo com esses autores mostra o fascínio das línguas e o modo como o tradutor as opera. Lançar luz sob essas considerações culturais da tradução e sobre a habilidade artística de que necessita o tradutor nos faz perceber a tradução como arte. Assim sendo, é evidente que na tradução não podemos nos deixar seduzir pela ânsia momentânea, mesmo que a língua nos "pareça" tão natural. É preciso valorizar e respeitar o papel dos tradutores e, antes de tudo, reconhecer que esse papel é fortemente marcado por uma visão de mundo e 180 pela capacidade que o bom tradutor possui de respeitar e decodificar situações, padrões e percepções de linguagem, ou seja, pela arte que possui de "compreender e interpretar", de utilizar as palavras e criar discursos.

Devemos valorizar esse ofício que é movido pela e para essência dinâmica e criativa que é a comunicação mundial. Sobral (2008, p. 117) nos diz que "O tradutor é um 'diplomata' sem país a defender, ele defende a possibilidade, a necessidade, e a riqueza do contato entre culturas". Hoje sabemos que o conhecimento vem carregado de uma postura investigativa e protagonista, que a pesquisa e a tradução andam juntas no ato de traduzir, e que todas as tecnologias estão a favor do tradutor, para facilitar o seu árduo trabalho, porém tais máquinas não poderão desenvolver a arte de traduzir. Ter essa consciência faz toda a diferença na hora de valorizar a profissão do tradutor, que na sua postura ética também deve manter-se sempre atualizado. Enxergar o tradutor como coautor do texto, não como máquina de equivalências ou o traidor de um texto, requer outro posicionamento capaz de redimensionar nossa avaliação do ato de traduzir.

Parafraseando Sobral (2008) e Schleiermacher (c.1805-1833/1999), nenhum de nós é inocente ao discursar, somos marcados por intenções mesmo que inconscientes. Portanto, o tradutor deve ser reconhecido como tal: protagonista, artista desse ato. A tradução deve ser vista como obra que é, constituída por autor, tradutor e leitor, através de uma união de 
saberes, vivências, culturas e formas de avaliar a vida, ou seja, constituída, como qualquer outra obra, por interpretações. A tradução pode ser pensada assim: uma obra artística que nunca é igual para nenhum de nós, mas especial para cada um. Enfim, é a busca pela fusão do pensamento do tradutor profissional, autor e leitor em uma língua com o do "outro" - autor, língua, leitor -, que torna a tradução eficaz. É durante essa busca que a arte de traduzir cria e recria a arte. A fim de que o leitor deste artigo reflita um pouco mais, finalizamos com as palavras de Paz (1971, apud BASSNETT, 2005, p. 61):

\begin{abstract}
Cada texto é único e, ao mesmo tempo, é a tradução de outro texto. Não há texto totalmente original, porque a própria língua, em sua essência, já é uma tradução: em primeiro lugar, do mundo não verbal e, em segundo, pelo fato de todo o signo e toda a expressão serem traduções de outro signo e outra expressão. Entretanto, este argumento pode ser invertido sem que perca a validade: todos os textos são originais porque toda a tradução é distinta. Toda tradução é, até certo ponto, uma invenção e, enquanto tal, constitui um texto único.
\end{abstract}

\title{
REFERÊNCIAS
}

ALVES, Afonso Telles (Coord.). Antologia de poetas estrangeiros VIII. São Paulo: Gráfica e Editora Epigraf Limitada, s/d. (Coleção LOGOS).

BASSNETT, Susan. Estudos da tradução. Tradução de Sônia Terezinha Gehring, Leticia Vasconselos Abreu e Paula Azambuja Rossato Antinolfi. 1. ed. Porto Alegre: Editora da UFRGS, 2005.

BENEDETTI, Ivone; SOBRAL, Adail. Conversas com tradutores. São Paulo: Parábola, 2003.

CARVALHO, Castelar de. Para compreender Saussure: fundamentos e visão crítica. 13. ed. Petrópolis: Vozes, 2004, 1 ed. 2003.

CUNHA, Celso; CINTRA, L. F. L. Nova gramática do português contemporâneo. 3. ed. Rio de Janeiro: Nova Fronteira, 2001.

ECO, Umberto. Quase a mesma coisa. Tradução de Eliana Aguiar. Rio de Janeiro: Record, 2007.

NORD, Christiane. Text analysis in translation: theory, methodology, and didactic application of a model for translation-Oriented text analysis. Amsterdam: Atlanta, 1991.

PAZ, Otavio. Traduccíon: literatura y literalidad. Barcelona: Tusquets Editor, 1971.

PESSOA, Fernando. O Corvo. Tradução do poema de Edgar Allan Poe, The Raven. Disponível em: http://www.insite.com.br/art/pessoa/coligidas/trad/921.php. Acesso em: jul. 2013. 
RÓNAI, Paulo. A tradução vivida. 2. ed. Rio de Janeiro: Nova Fronteira, 1981.

SCHLEIERMACHER, Friedrich D. E. Hermenêutica - arte e técnica da interpretação. Tradução e apresentação de Celso Reini Braida. 1. ed. Petrópolis: Vozes, 1999.

SILVEIRA, Brenno. A arte de traduzir. São Paulo: Melhoramentos, 1954.

SOBRAL, Adail. Dizer o 'mesmo' a outros: ensaios de tradução. São Paulo: Special Book Services Livraria, 2008.

SOBRAL, Adail. Texto, discurso, gênero: alguns elementos teóricos e práticos. Nonada Letras em Revista, v. 1, n. 15, p. 10-26, 2010. Disponível em: http://seer.uniritter.edu.br/index.php/nonada/article/view/264. Acesso em: 16 set. 2013

TAVARES, Ildásio. A arte de Traduzir. Salvador: Fundação Casa de Jorge Amado, 1994.

VENUTI, Lawrence. The Translator's Invisibility: A History of translation. 1. ed. Londres: Routledge, 1995. Edição publicada em Francis \& Taylor e-Library, 2004. Disponível em: http://www.translationindustry.ir/Uploads/Pdf/venuti.pdf. Acesso em: ago. 2013.

ZILLY, Berthold . O tradutor do Sertão. São Paulo, fevereiro de 2013. Revista Língua 182 Portuguesa, São Paulo, ano 8, n. 88, p. 10-3, fev. 2013. Entrevista concedida a Vera Helena Saad Rossi.

\section{GLOSSÁRIO}

Discurso: Processo de mobilização de textos para a realização de projetos enunciativos. Espaço de linguagem em uso, endereçado por um locutor a um interlocutor, apresentando um tom avaliativo e remetendo a uma compreensão responsiva ativa (SOBRAL, 2010).

Hermenêutica: Na filosofia, hermenêutica é a ciência que estuda a arte e a teoria da interpretação.

Língua-fonte (LF): Língua utilizada no texto de origem.

Língua-meta (LM): Língua para qual o tex to será traduzido.

Linguística: É a ciência que se ocupa do estudo acerca dos fatos da linguagem, cujo precursor foi Ferdinand de Saussure.

Teoria da comunicação: Estudo sobre a comunicação social.

Texto: Objeto da atividade autoral de mobilização de recursos para a realização de algum projeto enunciativo a partir das relações locutor-interlocutor; é uma materialidade que traz potenciais de sentido realizáveis em situações de instauração de discursos (qualquer que seja sua materialidade - som, imagem, sinais etc.) (SOBRAL. 2010). 
RECEBIDO EM 10/11/2013

ACEITO EM 15/12/2013

${ }^{\text {i }}$ Currículo Lattes: http://buscatextual.cnpq.br/buscatextual/visualizacv.do?id=K4366896H9 